This is the accepted manuscript of the article, which has been published in Narrative inquiry. 2019, 29(2), 371-390. https://doi.org/10.1075/ni.19022.laa

\title{
The Paradox of Imagining the Post-Human World
}

Fictional and Factual Rhetorical Strategies in Alan Weisman's The World Without Us

Maria Laakso, Tampere University

Since the beginning of the twenty-first century, works depicting a post-human world have become a popular non-fiction genre. This kind of disanthropy is an extreme form of apocalyptic thinking. In this article, I examine one such disanthropic narrative, Alan Weisman's bestselling non-fiction book The World Without Us (2007), using the theoretical framework of narrative fictionality studies. The World Without Us falls between the conventional oppositional pairing of factual and fictional narratives. The book bases its rhetoric heavily on scientific facts-or at least on scientific expectations-especially in its use of interviews with scientists. Nevertheless, the core idea of a world without humans is inevitably fictional since the presence of readers makes the book's premise manifestly counterfactual and paradoxical. In my analysis, I adopt a rhetorical approach to fictionality and factuality to ask how particular techniques and strategies connected to fictionality and factuality are employed in Weisman's text in order to discuss the anxieties, desires, hopes, and fears of the possibility of human extinction.

Keywords: fictionality, factuality, thought-experiments, Anthropocene, referentiality

\section{Introduction}

Since the Industrial Revolution, human beings have had an observable impact on the Earth's geology 
and ecosystems. Humans are responsible for-among other things—rising sea levels, the melting of the polar ice caps, and the extinction of many species. The present period of the planet's history is often called the Anthropocene Age: the epoch of human impact on a geological scale (Trexler, 2015, pp. 1-2). The term "Anthropocene” has come to signify a cultural change, and it encompasses the many challenges entailed by the ongoing destabilization of the relations between nature and culture (Vermeulen, 2017, p. 868). As noted by Adam Trexler in Anthropocene Fictions: The Novel in a Time of Climate Change (2015), anthropogenic climate change and the growing awareness of the human impact on the surrounding ecosystem have not only affected the planet but also literature, media, and other forms of cultural meaning making. The existing discourse of climate change has fundamentally shaped our culture over the last forty years. The idea of the Anthropocene and the growing awareness of global warming have had profound implications for nearly all our reference points in the world. Climate change alters the forms and potentialities of art, and shared cultural narratives and imaginative processes are fundamental to engaging with climate change.

Despite all the existing scientific evidence, climate change has often been (and still is) approached as a contentious matter. For much of the twenty-first century, climate change has been the subject of many heated political debates, and the discussion has been dominated by issues of evidence, representation, and personal belief. Trexler (2015, pp. 2-5) notes that the Anthropocene as a concept productively shifts the emphasis from individual belief, thought, opinions, and choices to the larger scale, namely to human processes that have demonstrably occurred across cultures, economies, generations, and politics. In spite of the human imagination's finite sense of place and time and our limited ability to feel empathy towards non-human nature, the non-human aspects of climate change can at least be discussed by emphasizing geological processes and observable changes to the planet. This growing non-human orientation of ecological thinking has also been manifested in the Western apocalyptic imaginary. "Apocalypse” refers to the end of the world, the end of time, or the ultimate destiny of humanity, and it has become one of the common ecological tropes in fiction. Some theorists even talk about the millennial obsession with the apocalypse (see eg., 
Barton, 2016, p. 5).

Outside eschatological religious narrative texts, apocalypses hardly ever portray the complete end of the world. In modern apocalyptic narratives, the apocalypse is more likely to be some form of catastrophe (Heffernan, 2008, p. 6). Ecocritic Greg Garrard (2012) has termed the trope of the world after humans “disanthropy,” an extreme form of apocalyptic thinking. Disanthropic narratives are the result of a growing awareness of anthropogenic climate change and the possibility of the extinction of the human race in the future. The concept of a world without humans arguably dates back to the Romantic period with the publication of Mary Shelley’s The Last Man, which is widely considered one of the first post-apocalyptic novels. Early examples of disanthropy can also be found in modernist fiction, such as Virginia Woolf's To the Lighthouse (Garrard, 2012, pp. 40-41). Nevertheless, since the Cold War, artistic anxieties concerning the complete annihilation of the human species appear to have intensified (see Kohlmann, 2013, p. 652). The first wave of these narratives was caused by fears of nuclear Armageddon, but it already contained the seeds of environmental awareness and post-humanist cultural theory (Kohlmann, 2013, pp. 664, 672). With the growing sense of climate change and the Anthropocene, the idea of a post-human world has also become more popular. Apocalyptic thinking has even become a popular undercurrent within nonfiction. Examples of the non-fiction genre include television series like the National Geographic Channel's Aftermath: Population Zero (2008), the History Channel’s Life After People (2008, 2010), and Animal Planet's The Future is Wild (2002).

In this article, I focus on one particularly interesting example of disanthropic representation: Alan Weisman's bestselling popular science book, The World Without Us (2007). It imagines an extreme version of an apocalyptic future, namely the world after the sudden extinction of humans. The premise of Weisman's book is therefore fictional in the sense of being invented. The sudden disappearance of humans overnight is certainly artificial and thus, in this sense, a deeply unnatural scenario (on unnatural scenarios, see Alber, 2016, p. 43). Nevertheless, Weisman’s book mostly represents generic non-fiction. It is framed as non-fiction by its paratexts (for example, on the book's 
back cover) and marketing, and it mostly follows the generic conventions of non-fiction (on the generic distinction between fiction and non-fiction, see Walsh, 2007, pp. 44-46). The status of The World Without Us as either fiction or non-fiction is therefore complicated. It imagines, predicts, and produces a future narrative world in which human life has disappeared, but bases this world on scientific fact, drawing on a wide range of evidence from scientists and other experts from fields including evolutionary biology, bacteriology, and radioecology.

According to Trexler (2015, pp. 29-33), contemporary Anthropocene fictions often quite openly "incorporate" scientific facts into fiction. This is because the nature of the phenomenon of climate change is intangible: it is complex, fuzzy, and still partly contentious, so authors use scientific knowledge on the topic to make it understandable. Trexler argues that some literary strategies indicate the importance of science to Anthropocene fiction. The most visible strategy, for instance, is the frequent use of scientists as characters. The majority of novels about climate change include at least one scientist-character whose function is to enable writers to impart scientific information to readers in order to add believability to the speculation of such works.

Trexler (2015, pp. 33-34) also notes that Anthropocene fiction has been interpreted by critics in two ways: the novels have been read either as more or less factual representations of climate change as a scientific phenomenon or as cultural texts that represent the collective imagination of the human impact on the environment. Both ways of reading fail to register the complexity of Anthropocene fiction, since climate change novels are a challenge to the conventional oppositional pairing of fact and fiction. As Trexler (2015, p. 71) puts it: “Climate change and climate change novels are neither fact nor ideation. Categorically impure, they are artifacts assembled from heterogeneous things in the world.” Trexler's claims of categoric impurity could actually describe any fiction, because all fiction refers in one way or another to the real world outside fiction. Still, I consider his findings on the open uses of scientific facts in Anthropocene fiction valuable. The Anthropocene and climate change are phenomena that call for authors of fiction to lean on scientific knowledge in order to reinforce the assertiveness of their work, even though the generic frame 
remains fictional.

The World Without Us does not narrate anthropogenic climate change per se, but rather envisions the assumed recovery of the planet and all its ecosystems after the disappearance of humans. Still, the starting point of the book is the human impact on the planet and its ecosystems: "we've poisoned or parboiled the planet, ourselves included" (Weisman, 2007, p. 4). For this reason, it certainly belongs to Anthropocene literature, even though it represents generic non-fiction instead of the fiction that Trexler discusses. Whereas climate fiction incorporates scientific facts into fiction, it could be assumed that non-fictions dealing with questions about climate change and the Anthropocene do the opposite: they utilize the narrative communicational strategies more common to generic fiction in order to discuss the fuzzy topic of climate change and the impact of humans on nature within the Anthropocene. In this article, I examine the uses of signaled fictionality within The World Without Us as a piece of generic non-fiction. In the next section, I introduce the theoretical frame of fictionality studies, including recent discussions of factuality. My analysis firstly explores the rhetorical fictionality of Weisman's book and considers the rhetorical meanings of facts presented in the text. Secondly, I consider the referentiality of the text and the predicted future world it constructs. Thirdly, I analyze The World Without Us as a thought-experiment-a text type that commonly falls between the classifications of generic fiction and generic non-fiction. I end my article by considering the ecological message of the text as it imagines the world without humans.

\section{Fictionality and factuality}

Schaeffer (2012) states that “[f]actual and fictional narratives are generally defined as a pair of opposites," but notes that this division is not founded on any clear rationale or evidential logic. Recent discussion has moved away from the generic distinction between fiction and non-fiction. Whereas formerly fictionality was investigated as the qualities, characteristics, and affordances of the 
fiction genre, lately it has often been approached as a discursive category-in other words, as a specific way of communicating with specific means and ends (Gjerlevsen \& Nielsen 2017). One of the first theoretic openings to the rhetorical approach to fictionality was Richard Walsh's Rhetoric of Fictionality (2007). Walsh's book in turn developed earlier pragmatic approaches, such as John Searles' ideas in "The Logical Status of Fictional Discourse," and approaches fictionality as a specific communicational strategy utilized across different media and genres. Narrative studies of fictionality that have continued to place emphasis on fictionality as a communicative strategy have since been classed as following the rhetorical approach, the foundation of which is Phelan's well known rhetorical approach to narrative as "somebody telling somebody else on some occasion and for some purpose(s) that something happened” (Phelan, 2005, p. 18). Nielsen, Phelan, and Walsh (2015) jointly apply this approach in their article “Ten Theses about Fictionality” by asking the question: "When, where, why and how does someone use fictionality in order to achieve what purpose(s) in relation to what audience(s)?” (p. 62). Fictionality is therefore the intentional use of invented stories and scenarios.

Gjerlevsen and Nielsen (2017) have subsequently developed the rhetorical approach by explicating the definition of fictionality. As they emphasize, the original claim in "Ten Theses" concerning fictionality as intentionally signaled, communicated invention implies several important aspects. The central notion is invention, which Gjerlevsen and Nielsen name as the central distinguishing feature of fictionality. In general, human beings have an ability to invent, but by employing the word “communicated,” they emphasize that this ability must always be manifested in communication in order to be classified as fictionality. This means that fictionality cannot be simply equated with invented objects and pure imagination; it must be part of a communicative situation with a sender and receiver. Gjerlevsen and Nielsen (2017) also note that fictionality must also be signaled in order to be recognized by the receiver as fiction. It is noteworthy that this can happen within a global frame of non-fiction. The intentionality in this definition emphasizes the communicator, who deliberately uses fictionality and in doing so distinguishes fictionality from lies. 
My use of the term fictionality in this article is in keeping with the definitions offered by narratologists working on the rhetorical approach. Fictionality in this sense does not signal a genre; rather, it is a quality of fictive discourse. Nielsen et al. compare fictionality to irony and ironic discourse. Just like irony, fictionality can be either global or local, and it can provide a framework for understanding the whole text, but it can also appear within a text that belongs to a different generic framework - for example, non-fiction (for more about local and global fictionality, see Phelan, 2016; see also Hatavara \& Mildorf, 2017a, 2017b; Iversen \& Nielsen, 2016). Fictionality must therefore be treated as a specific communicational strategy (Nielsen et al., 2015, pp. 62-63) that can appear locally within a non-fictional frame of reference.

Hatavara and Mildorf have discussed hybrid fictionality in their article "Hybrid Fictionality and Vicarious Narrative Experience” (2017b). They similarly argue that the signposts of fictionality can be used locally in narratives globally marked as non-fiction. Hatavara and Mildorf investigate conversational and documentary forms of storytelling (namely an interview and an online museum exhibition that both represent non-fiction) and, in doing so, they show that factual genres are no more stable or self-contained than fictional genres; they migrate and mutate all the time. This has been especially obvious in the field of contemporary factual television. Various kinds of news, current affairs, documentary, and popular factual genres like reality TV challenge the generic boundaries between fiction and non-fiction (Hill, 2007). Disanthropic TV narratives are a good example of this. The documentary series Aftermath: Population Zero, Life After People, and The Future is Wild all mix generic factuality and fictionality. They frame the depicted post-human future with "what if" projections that can be extrapolated based on known facts.

Just as fictionality has been the topic of recent critical debate in narratology, factuality has started to garner renewed interest, as indicated by the forthcoming Handbook of Factuality (Fludernik \& Ryan, 2019). Written journalism has contained a mixture of factuality and fictionality for decades. Indeed, narrative journalism and literary journalism tolerate ambiguity, imagination, creativity, and subjectivity far more than earlier, more traditional forms of journalism (Roberts \& 
Giles, 2014; see also Browse \& Hatavara, 2019). In his article in this issue, Samuli Björninen analyzes rhetorical factuality within the generic frame of narrative journalism. According to Björninen, a certain “effect of factuality” can be produced by appealing to culturally, historically, and generically variable types of authority. Such local, rhetorical appeals to factuality are also signaled in Weisman’s book, as I will now demonstrate in my analysis.

\section{Knowing and imagining a world after people}

According to the classification of its publisher, the generic frame of The World Without Us is nonfiction. This is marked by contextual or paratextual signals (see Walsh, 2007, p. 45; Hühn, 2014, p. 159), such as commercial classification. The non-fiction label is also given to this book by bookstores and libraries. The organizational structure of the book further signals its status as generic non-fiction: The World Without Us is divided into 27 chapters, each introducing a new topic or new point of view on the post-human world. These chapters explore, for example, the future of the plastics people will leave behind, the future of birds after people are gone, and the future of nuclear facilities when human beings are no longer around to maintain them. The speaker narrates to the reader certain chains of events, which would be typical of any narrative fiction. Still, the structural composition of the whole book is not driven by the plot as it is in prototypical fiction (i.e., the novel). Rather, the composition borrows its form from scientific texts. Each chapter proposes (often implicitly, between the lines, or in the heading) a certain kind of research question.

Terming a narrative product a "non-fiction" is a decision that often appears to be more socially manufactured and negotiated by the reader, author, and publisher than derived from some empirical standard of truth (Flis, 2010, p. 7). This is also true with Weisman's book. Even though the book's knowledge base is heavily scientific, its launching point is a call for the reader to participate in wild imaginary play: 
[P]icture a world from which we all suddenly vanished. Tomorrow.

Unlikely perhaps, but for the sake of argument, not impossible. Say a Homo sapiens-specific virus_-natural or diabolically nano-engineered—picks us off but leaves everything else intact. Or some misanthropic evil wizard somehow targets that unique 3.9 percent of DNA that makes us human beings and not chimpanzees or perfects a way to sterilize our sperm. Or say that Jesus [--] or space aliens rapture us away, either to our heavenly glory or to a zoo somewhere across the galaxy. (Weisman, 2007, p. 5.)

Weisman instructs the reader to imagine the extinction/disappearance of humans. Here it is noteworthy that Weisman refers playfully to generic fictions: An "evil wizard” targeting human DNA, “space aliens,” and a “diabolically engineered virus” are characters and tropes from science fiction or fantasy rather than serious threats to human existence. By referring to these conventionally invented characters and tropes, the communicator signals these reasons are not to be understood as something that actually could happen. Within a global frame of non-fiction, Weisman initially employs fictionality as a communicational strategy. As Garrard (2012, p. 51) notes, this quite extraordinary rhetorical maneuver liberates Weisman, allowing him to imagine and narrate the future of the world without any human presence: the reclamation of cities, the lingering toxins in the ecosystem, and the annihilation of our culture after humans are long gone. The launching point of the book is artificial and impossible, but it is needed to be able to discuss the future of non-human nature.

Obviously, the basic problem of predicting the future is that it cannot be known with absolute certainty. The World Without Us is an effort to know the future after an (unlikely) sudden human extinction. Still, not all future predictions can be treated as fictionality, because not all are signaled as such. In Weisman's book, the problem of knowing the future is approached by underlining the fictionality of the starting point of this imaginary play, but paradoxically also by signaling that the 
future after humans may be known. The latter rhetoric effect is achieved with two argumentation strategies: firstly, by referring to what has already happened and processes already witnessed; and secondly, by referring to "research" and expertise. The first strategy entails that the future is predicted based on historic events. Thus, the post-human world is narrated and imagined through recourse to knowledge about nature as it existed before humans, with the narrator extrapolating this knowledge to the world after humans. The second strategy entails the embedding of a wide range of interviews with scientists and other experts. Within the genre of journalism, the use of expert interviews or existing research results is a traditional signal of factuality. Interviews borrow the authorial voice of the expert, and texts can emphasize the truth-value of what is said in this way. The authority of the narrating voice is constantly emphasized in The World Without Us by referring to a certain interviewee or "research," which, for instance, "suggests that more birds die by simply colliding with powerlines than from being zapped by them” (Weisman, 2007, p. 249). This is part of the ethos of the text. As Liesbeth Korthal Altes (2014, p. 7) notes in Ethos and Narrative Interpretation, the reader always establishes the narrator's or author's ethos, which helps the reader to "get” his or her tone and assess how the represented actions and perspectives are to be taken. The speaker's stance in The World Without Us is in this sense two-fold. The authorial voice of the texts can be playful, like in excerpt quoted above, or authoritative and knowing.

However, the knowledge of the authority also has interesting fractures. The following excerpt is from a chapter called "Polymers are forever," which evaluates the fate of plastic. The expert interviewed is Richard Thompson, a marine biologist from the University of Plymouth. Thompson is asked whether plastics would start to break down naturally, and assuming they did, whether they would release dangerous chemicals sometime far in the future:

Richard Thompson didn’t know. Nobody did, because plastics haven’t been around long enough for us to know how long they'll last or what happens to them. His team had identified nine different kinds in the sea so far, varieties of acrylic, nylon, polyester, polyethylene, 
polypropylene, and polyvinyl chloride. All he knew was that soon everything alive would be eating them. "When they get as small as powder, even zooplankton will swallow them." (Weisman, 2007, p. 146.)

The text uses some traditional or generic rhetorical signals of factual discourse. The author here appeals to the authority of an academic expert, whose expertise is emphasized by use of the specific terminology of different forms of plastic. The free direct speech at the end of the excerpt accentuates that this is what the interviewee said, without the author's interference. By appealing to the authority of the biologist, the text creates a certain kind of referential connection to the reality outside the text. However, the interviewed marine biologist cannot answer the questions. Paradoxically, this ignorance also becomes an important part of the text's rhetoric. The first sentence proclaims some shocking information: if Thompson does not know, no one does. The unknowability of the future of plastics becomes horrifying proof of the fact that regardless of all the expertise we have gathered, we do not know the future. This kind of argumentation justifies the use of fictionality in other parts of the book. If the future cannot be fully known, it must be imagined. This is the unwritten rule of the whole book. Indeed, the limitations of human knowledge are highly important to the ethos of the text. The post-humanist worldview of the book does not, at least fully, believe in the human ability to correct their actions. Weisman's book tells us that regardless of all the human knowledge and expertise, nobody really knows the future with absolute certainty, but what we do know shows that we should respect nature instead of destroying it. Here the form of the text and the message intertwine.

Above, I have discussed the certain rhetoric appeals to factuality, which I located in the authoritative voice and borrowed authority of interviewed experts. By signaling factuality, the text contests reliability, but at the same time certain fractures of reliability are important to the communicated ecological theme of the book. Compared to the factual discourse in the scenes that include interviews with experts, the playful invitation to the reader to imagine a post-human world at the beginning of the book is very different. The excerpt analyzed above shows how such a local 
fictionality can be utilized within the global generic frame of non-fiction in order to achieve some rhetorical purpose, which here is to allow an imaginative scenario, albeit one that is observed carefully. I will next discuss whether The World Without Us should be treated as a thought experiment, and how thought experiments are related to the rhetorical uses of fictionality.

\section{Thought experiments and scenarios as forms of narrative fictionality}

As Nielsen et al. (2015, pp. 63-64) remind us, fictionality is founded upon the basic human ability to imagine. Many non-fictional textual or other practices are therefore fundamentally based on imagining. Rhetorically signaled fictionality is also utilized in thought experiments, scenario thinking, risk assessments, and many societal and political fields. We constantly employ fictionality outside generic fictions, and therefore the non-fictive discourse is always full of "hypotheticals, counterfactuals, speculations and other deviations from the actual” (Nielsen et al., 2015, pp. 63-64). "What if" projections, "if only" regrets, and thought experiments can all be part of the field of fictionality. According to this meaning, the scientific discourse of hypothesis is also based on scenarios.

The following excerpt is from the beginning of the book. Here Weisman prompts readers to first imagine their own everyday surroundings and then imagine the same location but without any humans:

Look around you, at today's world. Your house, your city. The surrounding land, the pavement underneath, and the soil hidden below that. Leave all in place but extract the human beings. Wipe us out and see what's left. How would the rest of nature respond if it were suddenly relieved of the relentless pressures we heap on it and our fellow organisms? How soon would, or could, the climate return to where it was before we fired up all our engines? (Weisman, 
Here the text signals the movement to the mode of fictionality through direct address to the reader: The speaker invites the reader to consider a certain scenario, namely the unexpected disappearance of humans. The crucial instruction to the reader is "Wipe us out." The pronoun "us" binds the reader and the speaker together as humans, as those to be wiped out. Already the name of the book strongly suggests a certain position to the reader. The title is not "The World Without Humans" but The World Without Us, where we-the author, the readers, and all other humans - are denied agency in the fictive world this book imagines. Paradoxically, the first-person plural in the narration personalizes humans and therefore commits the reader even more strongly to the act of producing a world without her/himself. The reader is therefore asked to commit a kind of self-erasure. From the point of view of narrative studies, the fictional future world without human subjects poses an interesting dilemma in terms of narrative subjectivity and narrating human experientiality (Fludernik, 1996, pp. 12-13). As an essential human sense-making activity, the narrative process is always inherently anthropocentric, because the frame of reference is human experientiality (Fludernik, 1996, p. 13; Walsh, 2007, p. 106; Caracciolo, 2018, p. 304). This is something I will discuss in more detail in the next section. For now, I will concentrate on the launching point of the book as a rhetoric move that frames the whole work as a thought experiment.

The inventive nature of the imaginative task is openly communicated to the reader in hypothetical formulations: "if" and "would" underline that which follows is only one possible scenario of many. It is important to note that the speaker does not translate non-fictional subject matter into something fictional, but rather the speaker adopts a communicative stance from where he invites the audience to recognize that he has temporarily stopped conforming to the limitations of referentiality in order to accomplish some rhetorical end. The author and his audience share an understanding of the borders between fictionality and non-fictionality (see also Nielsen et al., 2015, p. 62). Here, the movement to fictional discourse is marked so clearly that there is no doubt the 
reader would not recognize this rhetorical move.

The disanthropic scenario of The World Without Us is an interesting concept among "what if" projections, "if only" regrets, and thought experiments. Scenarios are also connected to the blend of factual and fictional rhetoric. Scientific discourse is based on scenarios, as every hypothesis is itself a scenario. Consequently, one can reasonably argue that scenarios sit at the crossroads of scientific and fictional discourse, at a place where their boundaries are blurred. Weisman's disanthropic vision can also be classified as a thought experiment, a classification closely related to scenario thinking and “what if” projections. In his article "Fictional vs. Factual Narration” (2012), Jean-Marie Schaeffer defines thought experiments as counterfactual deductive devices giving rise to valid conclusions that are integrated into a real-world belief system. Thought experiments are forms of fictionality widely used in philosophy or other fields of research, such as physics. Thought experiments differ from other scientific experiments in that the actual experiment is not meant to be conducted physically. The experiment takes place only at the level of the imagination, and it is communicated as such.

Thought experiments are often classified as short fictional narratives (fictional in the generic sense) used within the genre of scientific writing (Egan, 2016, p. 139). It remains questionable whether or not works of literary fiction can be treated as thought experiments, even though there are a number of similarities between thought experiments and other kinds of fictional narratives (see Klauk, 2011, p. 30). David Egan (2016, p. 139) has noted that this analogy between thought experiments and literary narrative fiction is often used when discussing the epistemological value of fiction - that is, how works of fiction can be sources of knowledge. The thought experiment is a valuable tool that makes it possible to experiment with ideas. In this sense, I find it justifiable to classify Weisman's book as a thought experiment, even though the global frame of the text is nonfictional and this thought experiment is book-length. The rhetorical aim of the act of "wiping us out" is to enable the sketching of a world suddenly without humans, even though this kind of disappearance is unlikely. In The World Without Us, the thought experiment is used to gain or offer knowledge about the power relations between humans and non-human nature. 
Understanding The World Without Us as a thought experiment does not mean it should also be understood as literary narrative fiction; rather, it shares some qualities of literary narrative fiction. Egan (2016, pp. 140-143) specifies several features that dissociate thought experiments from literary narrative fictions. For example, unlike literary fictions, thought experiments are used to make arguments, and the types of criticism we apply to thought experiments and works of literature differ. Egan's reasoning seems to be connected first to the rhetorical purpose of utilized fictionality within argumentation (even though Egan does not refer to the rhetorical theory of fiction) and second to the reception these thought experiments receive (criticism). It is remarkable that he does not argue that thought experiments and literary narrative fictions are essentially different; he rather states that the use of thought experiments in a rhetoric sense is different. The same reasoning is used by Klauk (2011, p. 32), who presents the three steps philosophical thought experiments typicallyhave:

a. We imagine a scenario.

b. We judge the scenario concerning a certain question.

c. We make use of this judgement.

Most literary fictions do not feature all of these steps. Even science fiction narratives, which often utilize the form of a thought experiment, lack the evaluation or judgement of the presented argument (within the text-readers can still evaluate the credibility of the scenario in their reception). Weisman's non-fiction book, on the other hand, includes all three steps, even though the form of the book does not seem to follow the more traditional form of the thought experiment as a short narrative within a longer argument. Steps b and c are taken in the book's final chapter, where the author discusses his preceding chapters and demonstrates his thought experiment:

Yet the biggest elephant of all is a figurative one in the planet-sized room that is even harder to ignore, although we keep trying. Worldwide, every four days human population rises by 1 million. Since we can’t really grasp such numbers, they’ll wax out of control until they crash, as has happened to every other species that got too big for this box. About the only thing that 
could change that, short of the species-wide sacrifice of voluntary human extinction, is to prove that intelligence really makes us special after all. (Weisman, 2007, p. 348.)

The speaker addresses readers here through several scaled metaphors: planet Earth is represented as a room or box, both of which are limited spaces and in danger of becoming too crowded, and population growth is the 'elephant in the room'. These metaphors of scale attempt to make the often abstract and multifaceted problem of the Anthropocene understandable (about scales and Anthropocene narratives, see Caracciolo, in press). In this quotation - and throughout the final chapter of the book - the thought experiment of wiping out human beings is reflected on and concluded: it outlines what follows from all the information gathered on the "what if" projection of all humans disappearing. The rhetorical aims of the speaker are clear: this is a book with a strong ecological message, and it is emphasized in the final chapter. The carefully studied thought experiment of a vanished humankind turns out to be subordinate to the ecological message of posthumanism.

Thought experiments are a conventional way of utilizing fictionality within factual text types like science, and they are therefore a good example of local rhetorical fictionality. Even though The World Without Us does not use the thought experiment in the most traditional sense (that is, as a short narrative used to make a certain point), it certainly bases its argumentation on a thought experiment that is clearly signaled as fictional As I noted above, thought experiments are not to be confused with literary narrative fictions. Weisman’s book displays several narrative qualities, but, for example, in its lack of an overarching plot or experientiality of characters in the post-human world, it differs significantly from the form of the novel. In the next section, I will discuss the narrative qualities of Weisman's book, especially the world-building and the paradoxical nature of imagining a post-human world through human consciousness. 
According to many narrative theorists, every narrative leads to the construction of a world (Ryan, 2019; 2001; Schaeffer, 2012). Non-fictional narratives are no exception. For example, Marie Laure Ryan has shown that both fictional and non-fictional narrative texts invite readers to imagine a world:

The difference between fiction and nonfiction is not a matter of displaying the image of a world versus displaying this world itself, since both project a world image, but a matter of the function ascribed to the image: in one case, contemplating the textual world is an end in itself, while in the other, the textual world must be evaluated in terms of its accuracy with respect to an external reference world known to the reader through other channels of information. (Ryan 2001, pp. 92-93.)

The question of referentiality is important when analyzing fictionality, since fictionality is often connected to non-referentiality (see Hühn, 2014). For example, Dorrit Cohn (1999, p. 13) has compared fiction to historiography and emphasized that the former creates its referent world by referring to historiography. Non-referentiality seems to be a disjunctive feature of fiction as a genre. As Cohn points out, non-fiction is referential, whereas fiction can be-but does not have to bereferential. Of course, it would be hard to imagine a piece of fiction without any referential relation to the actual world outside of the narrative, since as many possible-worlds theorists and cognitive narratologists argue, narrative comprehension is always based on real-world cognitive frames and scripts. Ryan (1991), for example, uses the concept of the principle of minimal departure, which entails that readers alter their realistic expectations only when the narrative explicitly forces them to do so. Referentiality or non-referentiality are always matters of degree, even though compared to (generic) non-fiction, (generic) fiction is allowed to take more liberties with the reader's imagination.

Nielsen et al. (2015, p. 68) suggest that fictionality can generate an overlay of fictionality and referentiality: "Fictionality often provides for a double exposure of imagined and real." They argue 
that fictive communication can invite the reader to "map" an engagement with representations of "what is” onto "what is not." In turn, this mapping can affect the reader's sense of reality. This creates a "double exposure” of two worlds — the fictive world and the actual world—which can also be a double exposure of two times - the present and the future (Nielsen et al., 2015, p. 68). As such, fictionality may not be interpreted as being literally true, yet it is can have the capacity to shape our beliefs about the actual world (see also Gjerlevsen \& Nielsen, 2017).

The World Without Us continually entails a “double exposure,” since it overlays the fictional or hypothetical "what if" onto the present day. In the following excerpt, the book imagines what would happen if New York’s subway pumps stopped pumping.

Even if it weren't raining, with subway pumps stilled, that [the flooding of New York's subway system] would take no more than a couple of days, they estimate. At that point, water would start sluicing away soil under the pavement. Before long, streets start to crater. With no one unclogging sewers, some new watercourses form on the surface. Others appear suddenly as waterlogged subway ceilings collapse. Within 20 years, the water-soaked steel columns that support the street above the East Side’s 4, 5, and 6 trains corrode and buckle. As Lexington Avenue caves in, it becomes a river. (Weisman, 2007, p. 30.)

The "they" mentioned in the first sentence of this extract are New York City Transit's superintendent of Hydraulics and the level one maintenance supervisor of Hydraulics Emergency Response. Here again, we can see the rhetorical effect of borrowing the expertise of interviewees in order to strengthen the auctorial ethos of the text. In addition, the geographical referentiality of New York and the technical details suggest factuality. The train tunnels and streets are all existing places, details of the Big Apple's cartography. Despite these signals of factuality, the imagined future of New York's waters is inevitably invented - that which is depicted has not yet happened. The signals of this fictionality are given syntactically, using the conditionals "if” and "would" (as has been seen in 
examples from The World Without Us previously discussed; see also Gjerlevsen \& Nielsen forthcoming). The subsequent claim that steel columns "corrode and buckle" is not hedged with conditionality, though the adverbial phrase "within 20 years” does present this as a future scenario. Here, the text consequently combines the referential, factual frame of the geographically existing New York and the knowledge of the interviewees with a non-referential, fictional account of an uninhabited, flooded city. The excerpt offers a double exposure of the imagined and real in the sense discussed by Nielsen et al. (2015, p. 68).

With the constant use of the hypothetical and possible language clearly signaling fictionality in the textual rhetoric in addition to the constant movement between the temporal levels of "now" and the (hypothetical) future, The World Without Us actually constructs two different worlds with two different narratives. The first is the temporal now, where the experts and scientists in very different settings and geographical locations across the world answer the questions of the invisible interviewer. The journalist (Weisman) does not always reveal himself in these interviews, but clearly masters the text and leads the interviews in a certain direction. Whilst the story of a journalist traveling around the world and gathering huge amounts of information in order to understand the possible future of the planet after the unlikely disappearance of human beings is not narrated explicitly, the reader is likely to infer that this happened in order to generate the story of the book. Actually, this level of the story is explicitly narrated in the Acknowledgements, where Weisman tells readers about the writing process and thanks the "large supporting cast of humans" (Weisman 2007, p. 356); “cast” is interestingly fictionalizing, since it is drawn from the language of theatre and film. The second world is the hypothetical future world without humans. The construction of this world is generated with the help of many scientists and other experts to predict a world neither the author nor the reader will ever actually be able to experience. This second world is mostly signaled by hypothetical expressions that distance the reader from the experientiality of the post-human world.

An even greater distancing effect is the pure impossibility of a post-human world being experienced by humans. Monika Fludernik (1996, p. 13) has approached experientiality as reflecting 
a cognitive schema of embodiedness that relates to human existence and human concerns. As Marco Caracciolo (2018) notes, various aspects of narrative are thoroughly embodied: Real-world bodily experience helps the reader to flesh out storyworlds and their inhabitants. The body involved in our narrative comprehension is always the human body. For this reason, prototypical stories are inherently anthropocentric: they are driven by the human(-like) characters' intentions and focus on events that are "commensurable with the lifespan of human beings" (Caracciolo, 2018, pp. 304-305). The posthuman future world imagined in Weisman's book is therefore impossible precisely because it is beyond the reach of human experience. Furthermore, epistemological questions regarding the knowability of a post-human world make this world difficult to imagine (Kohlmann, 2014, p. 661). How can one narrate a world that exists without being perceived by humans? The following quotation is an example of such a narration that tries to portray what the post-human world would actually be like:

Ruins of high-rises echo the love song of frogs breeding in Manhattan’s reconstituted streams, now stocked with alewives and mussels dropped by seagulls. [--] With bridges finally down, tunnels flooded, and Manhattan truly an island again, moose and bears swim a widened Harlem river to feast on the berries. (Weisman, 2007, pp. 44-45.)

In this excerpt, Weisman depicts the future of post-human New York now populated by animals. Compared to the previous quotation I analyzed, it is notable that the hypothetical "if" and "would" are not utilized here, and the grammatical tense used is, exceptionally, the present-tense. The text invites the reader into an embodied imaginative experience by appealing to the soundscape filled with voices of breeding frogs and the sight of large mammals crossing the Harlem River.

In this excerpt, the readers get to experience the future as invisible observers. As readers, we are momentarily present in a future world empty of humans. The absence of the explicit narrator or focalizer makes it hard to localize the deictic center of the narration. Thinking about the reader's 
embodied cognition, the positioning of the reader is nevertheless unstable and floating. Who, then, is narrating the text or focalizing the world of The World Without Us in the excerpt above? Here Ann Banfield's (2019, p. 105) concept of the empty deictic center is useful. Banfield compares the empty deictic center to the representations produced by modern scientific instruments and photography. Such instruments have the ability to reveal times and places no one has ever seen before and the appearance of things no one is present to witness, such as outer space (Banfield, 2019, p. 105). A similar kind of effect is produced momentarily in this text. We can imagine an abandoned camera still recording even though the human race has already disappeared. However, this is not the deictic nature of the whole text. Soon, the author returns to the global frame of non-fiction and reminds the readers of the factual nature of his vision by interviewing art conservator Barbara Appelbaum. However, these kinds of flashes of the future world challenge the generic frame of non-fiction by allowing the reader a presence in a world that is obviously impossible to reach.

Pieter Vermeulen (2017, p. 876) has traced a new literary figure that appears in the literature of the Anthropocene; it is the trope of the posthumous reader who "remains to read the traces left by civilization. Such a future reader provides a perspective from which the tale of ongoing human error can be narrated with the benefit of hypothetical hindsight.” This impossible communicative situation, which is outside human experience but paradoxically captured by the anthropocentric worldview, makes disanthropic narratives an interesting combination of signaled fictionality and factuality.

\section{Conclusion, or how to die in the Anthropocene?}

"How long would it take to recover lost ground and restore Eden to the way it must have gleamed and smelled the day before Adam, or Homo Habilis, appeared?” (Weisman, 2007, p. 5), asks Weisman at the very beginning of his book. This question is part of the setting of the book, launching the thought experiment of what would happen if all humans suddenly disappeared. The quotation refers explicitly 
to the Biblical Eden myth and suggests that the whole human species should be seen as plague species without which the world would still be an earthly paradise.

As I noted in the introduction, the apocalyptic narrative is a tradition most often utilized in generic fiction (or religious texts). Post-human non-fiction apocalypses like Weisman’s book are very aware of the fictional genre in which they participate and consciously resist the genre of literary apocalypses, wherein the apocalypse is an opportunity for civilizational renewal (see Kohlmann, 2014, p. 662; Berger, 1999, p. 7). In Weisman’s book, the human-free world is not just a negative and terrifying vision of human extinction; the disappearance of humans would allow other species to live in a new earthly paradise. In contemporary society, the threats of global environmental crises and population growth encourage us to imagine the total end of the human race. In disanthropic narratives, this end is not necessarily represented as exclusively bad and terrifying - the imagined future without humans also has its utopian undertones. However, and despite the utopian undertones of the book, the primary rhetorical aim is to warn us as readers. With knowledge gained from numerous scientists and experts, Weisman proves that humans have already left footprints all over the natural world, marks that will remain long after we are gone. Weisman also warns that our destructive environmental behavior could at some point lead to our extinction, even though that would not happen as suddenly as in the scenario presented in the book.

My analysis of Alan Weisman's The World Without Us demonstrates that the book uses the rhetorical strategies of both factuality and fictionality in building this warning ethos and ecological message. As I have argued, the launching point of the book is clearly signaled as fictional: the reader is invited to participate in a thought experiment where humans are suddenly, unnaturally, and artificially wiped out. Despite this signaled invention being emphasized from the very beginning of the book, the experiment is performed carefully and with the application of a wealth of scientific knowledge. Weisman therefore also uses many of the rhetorical signals of factual discourse. The author constantly appeals to the authority of academic experts, and in this way the text creates a certain kind of referential connection to the reality outside the text, even though the future world 
without humans cannot be fully known. In its determined search for a future that is always impossible to know for sure, Weisman's book creates a vivid fictional post-human world, and the reader is openly invited to play along and participate in the thought experiment. At the same time, through signaled and communicated factuality, the reader is constantly reminded that this particular work is not just any random act of imagination; it is based on a huge amount of knowledge gathered from various fields of science.

Pieter Vermeulen (2017, p. 872) suggests that one of the most overlooked functions that narrative serves in our time is to alert us to the increasingly inescapable fact of the finitude of the human species (see also Gibbons, 2019). For Vermeulen, narratives of the Anthropocene are nevertheless also opportunities for humans to learn how to die in the Anthropocene- to learn how to accept that the world is not dependent on one species, not even ours. Even though The World Without Us serves as a warning, this is also one of its aims. Weisman's book is a thought experiment into what would happen to the natural and built environment if the entire human race suddenly disappeared. As such, it should be treated as both an intellectual and an emotional endeavor wherein the anxieties, desires, hopes, and fears of the possibility of a post-human world can be faced through known facts and the imagined experientiality of a world without us.

\section{References}

Alber, J. (2016). Unnatural narrative: Impossible worlds in fiction and drama. Lincoln/London: University of Nebraska Press.

Banfield, A. (2019) Describing the Unobserved and Other Essays. London: Cambridge Scholars Publishing.

Barton, R. (2016), Dystopia and the Promethean nightmare. In L. M. Demerjian (Ed.) The age of dystopia: One genre, our fears and our future (pp. 5-18). Newcastle: Cambridge Scholars 
Publishing.

Berger, J. (1999). After the end. Representations of post-apocalypse. Minneapolis/London: University of Minnesota Press.

Björninen, S. (2019). The rhetoric of factuality in narrative: Appeals to authority in Claas Relotius’s feature journalism. In this issue.

Caracciolo, M. (2018). Posthuman narration as a test bed for experientiality: The case of Kurt Vonnegut’s Galapagos. Partial Answers, 16(2), 303-314.

Caracciolo, M. (in press). Form, science and narrative in the Anthropocene. Narrative.

Cohn, D. (1999). The Distinction of Fiction. Baltimore, MD: The John Hopkins University Press.

Egan, D. (2016). Literature and though-experiments. The Journal of Aethetics and Art Criticism, 74(2), 139-150.

Flis, L. (2010). Factual fictions. Narrative truth and the contemporary American documentary novel. Newcastle: Cambridge Scholars Publishing.

Fludernik, M. (1996). Towards a “natural” narratology. London: Routledge.

Fludernik, M. \& Ryan, M-L. (2019). Handbook of narrative factuality. Manuscript submitted for publication.

Garrard, G. (2012). Worlds without us: Some types of disanthropy. SubStance, 41(1), 40-60.

Gibbons, A. (2019). Entropology and the end of nature in Lance Olsen’s Theories of Forgetting. Textual Practice, 33(2), 280-299.

Gjerlevsen, Z. S. \& Nielsen, H. S. 2017 Distinguishing fictionality. In C. Maagaard, M.W. Lundholt, \& Schäbler, D (Eds.), Fictionality and factuality: Blurred borders in narrations of identity. Berlin: Walter de Gruyter. Manuscript submitted for publication.

Hatavara, M. \& Mildorf, J. (2017a). Fictionality, narrative modes, and vicarious storytelling. Style, 51(3), 391-408.

Hatavara, M. \& Mildorf, J. (2017b). Hybrid fictionality and vicarious narrative experience. Narrative, 25(1), 65-82. 
Heffernan, T. (2008). Post-apocalyptic culture: Modernism, postmodernism, and the twentiethcentury novel. Toronto: University of Toronto Press.

Hill, A. (2007). Restyling factual TV [Kindle edition]. Londo/New York: Routledge. Retrieved from Amazon.com.

Hühn, P. (2014). The problem of fictionality and factuality in lyric poetry. Narrative, 22(2), 155168.

Iversen, S. \& Nielsen, H. S. (2016). The politics of fictionality in documentary form. European Journal of English Studies, 20(3), 249-262.

Klauk, T. (2011). Thought experiments and literature. T. Köppe, M. Butter \& D. Birke (Eds.), Counterfactual thinking - Counterfactual writing (pp. 30- 44). Berlin: De Gruyter.

Kohlmann, B. (2014). What is it like to be a rat? Early cold war glimpses of the post-human. Textual practice, 28(4), 655-675.

Korthal Altes, L. (2014). Ethos and narrative interpretation. The negotiation of values in fiction. Lincoln/London: University of Nebraska Press.

Nielsen, H. S.,Phelan, J., \& Walsh, R. (2015). Ten theses about fictionality. Narrative, 23(1), 6173.

Phelan, J. (2005). Living to tell about it. A rhetoric and ethics of character narration. Ithaca: Cornell University Press.

Phelan, J. (2016). Local fictionality within global nonfiction: Roz Chast’s Why can't we talk about something more pleasant? Enthymema, 16, 18-31.

Roberts, W. \& Giles, F. (2014). Mapping nonfiction narrative: A new theoretical approach to analyzing literary journalism. Literary Journalism Studies, 6(2), 101-117.

Ryan, M-L. (1999). Possible worlds, artificial intelligence and narrative theory. Bloomington: University of Indiana Press.

Ryan, M-L. (2001). Narrative as virtual reality. Immersion and interactivity in literature and electronic media. Baltimore/London: The John Hopkins University Press. 
Ryan, M-L. (2019). From possible worlds to storyworlds: On the worldliness of narrative representation. A. Bell \& M-L. Ryan (Eds.), Possible worlds theory and contemporary narratology. (pp. 62-87). Lincoln/London: University of Nebraska Press.

Schaeffer, J-M. (2012). Fictional vs. factual narration. The Living handbook of Narratology.

Retrieved from http://www.lhn.uni-hamburg.de/article/fictional-vs-factual-narration.

Trexler, A. (2015). Anthropocene fictions: The novel in a time of climate change.

Charlottesville/London: University of Virginia Press.

Vermeulen, P. (2017). Future readers: Narrating the human in the anthropocene. Textual Practice, 31(5), 867-885.

Walsh, R. (2007). The rhetoric of fictionality. Narrative theory and the idea of fiction. Columbus: The Ohio State University Press.

Weisman, A. (2007). The World Without Us. New York: Picador. 